\title{
Dialectic Critical Realism: Grounded Values and Reflexivity in Social Science Research
}

\author{
Christopher Bagley ${ }^{1}$, Alice Sawyerr ${ }^{2}$, Mahmoud Abubaker ${ }^{3}$ \\ ${ }^{1}$ Public Health Institute, Liverpool John Moores University, Liverpool, UK \\ ${ }^{2}$ Department of Continuing Education, University of Oxford, Oxford, UK \\ ${ }^{3}$ School of Management, University of Bradford, Emm Lane Bradford, UK \\ Email: *chrisbagley2@gmail.com
}

How to cite this paper: Bagley, C., Sawyerr, A., \& Abubaker, M. (2016). Dialectic Critical Realism: Grounded Values and Reflexivity in Social Science Research. Advances in Applied Sociology, 6, 400-419. http://dx.doi.org/10.4236/aasoci.2016.612030

Received: October 27, 2016

Accepted: December 5, 2016

Published: December 8, 2016

Copyright $\odot 2016$ by authors and Scientific Research Publishing Inc. This work is licensed under the Creative Commons Attribution International License (CC BY 4.0).

http://creativecommons.org/licenses/by/4.0/

\begin{abstract}
Critical realism emerged from the philosophical writings of Roy Bhaskar, and has evolved into a philosophy of social science research using the model of "dialectical critical realism" (DCR) which begins with the researcher's assumptions that the structures being researched have a real, ontological grounding which is independent of the researcher. This approach has proved fruitful in British and European social science research, but has had less influence in North America. We outline DCR's four-level model for understanding society and its changing social structures through "the pulse of freedom". DCR has been used by Marxists, Muslims, Catholics and secular scholars who engage fruitfully in morphogenic dialogues leading to a critical realist understanding of society and social research, which transcends positivist and social constructionist models. Examples of DCR's application in the fields of childhood research, child abuse, education, and research on organisations are outlined to illustrate the working of this new research paradigm. We are enthusiastic in our advocacy of DCR as a model of qualitative research, and for constructing models of positive social change, and are particularly impressed by the substantive and theoretical expositions of DCR by Priscilla Anderson, Matthew Wilkinson and Margaret Archer, whose work we document and review.
\end{abstract}

\section{Keywords}

Dialectical Critical Realism, Education, Marxism, Islam, Alienation, Child Abuse, Work-Life-Balance

\section{Introduction to the Concept of Dialectical Critical Materialism}

The concept of Critical Realism and its later development using concepts from Hegel and Marx are known as dialectical critical realism (DCR), and come from philosophy, 
rather than social science. Its basic literature of explanation uses philosophical language and reasoning, which is often challenging for the social scientist who has had no grounding in formal logic, or in the discipline of philosophical analysis. DCR is not an account of social science, but rather a philosophy of how knowledge about people and their social structures may be construed, interpreted, described and fitted together. DCR assumes that although the ground of knowledge is real, it also has a value base: there is no such thing as value-free social science.

Critical Realism (CR) clearly prefers social science research which employs qualitative, case-study methods, but acknowledges that multiple methods (including surveys and statistical analyses) can be used in order to gain the fullest information about "a case" (Alderson, 2013).

Critical Realism emerged from the writings of the philosopher Bhaskar (1986) who was seeking an alternative to what he saw as ambiguous and often confusing models of scientific methodology, particularly, the Popperian doctrine of "falsifying hypotheses" Popper (2002). Bhaskar extended his critique to the methodologies of social science, attempting to find a way forward from what he saw as the stultification and confusion of "positivism", "phenomenology", "post-modernism", and "social constructionism". Critical Realism has been attractive to social researchers, and theorists who are committed to a firm ideological basis for viewing human action (e.g. Marxists, Muslims, Catholics) in asserting that structures within society are real and although their nature and influence may be debated, their being or ontology (e.g. class exploitation, alienation, the nature of spiritual being) is not in doubt (Archer, 2014).

It is of course possible that Marxists and Catholics will disagree profoundly on what are, or should be salient aspects of "realism" (Creaven, 2007), but CR nevertheless also lays the way open for dialogue and compromise between seemingly incompatible systems through the process of dialectical critical realism in Bhaskar's later work (Bhaskar, 2008). Bhaskar adapts the Hegelian model of dialectical debate (traditionally: thesis, antithesis, synthesis) but goes beyond this model in positing a fourth level in the dialectical process which leads to action for, or advocacy of change. Moreover, this process of dialectical critical realism (DCR) is a continuous process in the lives of social systems, dyads and individuals, and there is continuous feedback between the "agents" (the actors or individuals in DCR), or between various individuals: through these reflexive ideas and exchanges, organisations are in a process of continuous change and adjustment to new feedbacks, and the changing of social structures.

At this stage, a challenge in reading CR theoretical texts and research emerging from CR theory should be mentioned: Critical Realism has developed its own vocabulary, and has coined new words ("neologisms") which the student may have difficulty in learning, or retaining. Furthermore, common English words are used in a way which attributes a rather different meaning to that of everyday language. The use of the word absence is a case in point. The difficulty of grasping CR concepts may be illustrated by this quotation from Alderson (2016): “Absence as a noun or verb is central to the DCR process of a bsenting absences, constraintsills, contradictions, oppressive power, rela- 
tions or inequities. Absence is the crucial empty physical, social and mental space that enables movement, imagined alternatives, processes and change." (p. 166) Thus "absence" actually means (in some, but not in all situations) the presence or existence of some positive force for social change ${ }^{1}$. Despite the complexities of her CR model, Alderson (2013 \& 2016) in her two volumes on The Politics of Childhood Real and Imagined has many valuable things to say, and we have tried to utilise her insights in this paper.

What one finds in CR writing is an absence of dogma, and a willingness to engage in debate (the essence of DCR) to reach compromise. Thus Collier (1999) offered a useful synthesis of Weber's “individualism" and Durkheim's "collectivism" showing (pp. 144-145) that these are not alternative models of individuals within social systems, but in the DCR mode, interactive models, which coexist and offer simultaneously, ways of promoting social action for change: individuals co-operate collectively, but remain individuals, is the message. Thus, in Collier's analysis [9] of Marx's writing on Capital, most wage earners are mystified by the nature of capitalism that exploits them: their alienation remains unmasked (Marx, 2013; Collier, 1999). But in the Dialectical Critical Realist model they are capable of understanding and changing both their modes of thought and their social actions, their necessary "underlabouring" (using a term borrowed from Locke) in addressing capitalist exploitation. The worker who fails to grasp the nature of his or her exploitation remains in a state of "non-realism", of "absence", Collier (1999) asserts (p. 12) [9]. In response to critics of this Marxian approach, Collier (1999) says: “...modern non-realists often accuse realists of dogmatism because of our defence of objectivity. They accuse us of arrogance in claiming truth for our theories... [but]... To claim objective truth for one's statements is to lay one's cards on the table, to expose oneself to the possibility of refutation." (p. 13) [9].

This bold claim to recognise "reality" (which is, of course, initially an intuitional process) rejects postmodern ideas of the relativity of knowledge and the impossibility of constructing linear models of basic cause; and also rejects social constructivist ideas that knowledge and values are relative, and are generated through unique sets of social interactions. One understands why $\mathrm{CR}$ has proved attractive to the Muslim scholar Matthew Wilkinson (2015). In "making sense" of his experience of teaching in a Muslim school he says: "...this book draws upon the tradition of dialectical European philosophy, epitomised by Hegel... Most recently, this tradition has been brought with great energy and conceptual sophistication into the contemporary academy by the founding figure of the philosophy of critical realism, Roy Bhaskar, as well as others following his lead, such as Alan Norrie, Andrew Wright and Margaret Archer. CriticaIrealism is exceptional in its coherent articulation of a contemporary philosophy of be-

\footnotetext{
1“At its philosophical core lies a theory of absence, which Bhaskar combines with his pre-existing arguments from critical realism for the significance of ontology. This is a basis for the realist understanding of human being in society and in nature which, through the account of absence, is aligned to a theory of becoming and change in a spatio-temporal world. The alignment of being and becoming is achieved in a manner that displays both a uniqueness of individual philosophical voice and boldness of intellectual vision, and these gave Bhaskar a fair claim to stand... in the first rank of western philosophy today.” (Norrie, 2010: p. 3) [8].
} 
ing, of knowing and real personal, ethical and social change, and its refusal to reduce being of all types, including spiritual being, to socially constructed epistemology or merely psychological or semantic meaning. This makes the philosophy of critical realism at its original, dialectical and spiritual moments an ideal vehicle for the development of a systematic rationale to interpret Islam and Islam-in-education in a multi-faith world." (p. 10).

Wilkinson draws on both Islamic and critical realist thinking in arguing that Muslim education should be "a philosophy for success", or empowerment (or, as Marxists would put it, the unmasking of alienation). Success is seen by Wilkinson as embedded in the multidimensional development and self-realisation of human social interaction within and between the four planes of social being defined by CR theorists. These planes are:

The Real: material transactions with nature (e.g. "the ground of being", "the essence of humans", "the uniqueness of each human being" counterpoised with forces of nature, polity and economy which impose themselves on humans; and the divine revelations regarding human conduct, of various world religions);

The Actual: Inter-subjective (interpersonal) transactions between individuals or "human agents" in different settings, including socialization and social control; the imposition of racialized identities; economic deprivation; forced migration et alia: and the understandings which humans have of these controlling forces, in dialogue, in writing, in protest, in political movements;

The Empirical: Social relations at the non-reducible level of social structures, institutions and forms;

The Transcendent: The embodied personality's liberation through mutual tolerance, the shedding of false consciousness, spiritual fulfilment; awareness of self potential, self-actualization. (Adapted from Bhaskar, 2008-this is also the basis of Alderson's (2013 \& 2016 MELD model explained below).

Wilkinson (2015) focuses his analysis on "the embodied personality" and his or her spiritual, intellectual, affective-cultural, civic, and instrumental dimensions. Each of these dimensions has distinct and interrelated or "articulated" ontologies. "Ontological realism" concerns the philosophical study of being (the first level of being in CR theory), and is a central concept within DCR: "A basic understanding of critical realist ontology, the philosophical study of being is... that being exists independently of our knowledge of it and in particular, our ability to describe it, so that it cannot be reduced to discourse, nor is it merely contained or constructed in the semiotics of our speech."

\section{Priscilla Alderson and the Politics of Childhood}

Alderson (2016) in construing "the politics of childhood" offers the following explanations of DCR's 4-levels of analysis, which, following Bhaskar (2008), she terms MELD. The first level is 1M-DCR concepts of basic reality e.g. moral realism, which consists (in social science) of ethical naturalism. The "moral realism" inherent at this basic level of DCR “...accepts that harm and benefit are universal, causal, moral realities, which are 
defined and experienced in varied local and personal ways. To deny moral realism would set up theoryl practice inconsistency... Because humans are vulnerable, sensitive, social beings, able to flourish and to suffer, moral realism is part of human nature and daily life, and is not artificially introduced (see Archer, Bhaskar and Collier) ...1M seeks to avoid the anthropic fallacy that places humans at the centre of the purpose and meaning of the universe (Bhaskar). Instead, 1M sees that we are part of nature... A related problem is the adultist fallacy. This sets rational adults at the apex of morality, and regards childhood as a slow climb up from lower, natural, pre-social, pre-moral babyhood to higher, socialised, moral adulthood." (Alderson, 2016: pp. 28-29).

Priscilla Alderson in her two volumes on 'the politics of childhood' (2013 \& 2016) offers a vigorous and often moving account of the children she has been involved with in her research over a 30-year-period, but admits that she is a recent "convert" to DCR: "The challenge of rethinking my past research in relation to DCR, and of writing this book, has helped me, and I hope it will help readers, to see how DCR enlarges research theory and analysis. Since learning about DCR, I have revised some of my former ideas and discarded others, on the continuing journey of learning and changing." (Alderson, 2013: p. 8).

Alderson terms the second level in her DCR analysis 2E (second edge) "...which concerns the transition into intervention and process in product. $2 \mathrm{E}$ concerns actively negating problems that were identified at $1 \mathrm{M}$ (Bhaskar, 2008: 97-98). This involves absenting aporia (contradictions and constraints, ills and untruths)..." (Alderson, 2016: p. 34). Exactly how this is done is problematic however, and often one is challenged to know where to "fit" one's research findings within the four levels of analysis, and how to interpret findings (and undertake further research) in terms of absence, dialogue, dialectic or change-for example, the research studies on children which Alderson presents us with.

We move to Alderson's third level called 3L. She terms this level the totality of change, and comments "...3L recognizes that we all share a core universal human nature, our common humanity, [but] we are all unique and ethically different... We are interconnected and interdependent, dialectic replaces dichotomy, "is" connects to "ought" and "ought" connects to "can" (Bhaskar, 2012: 146-148)... “(Alderson, 2016: p. 41). It is at this level of understanding social structure that Margaret Archer's ideas (1995-2012), of morphogenesis (personal change through dialectic interchange, and self-reflection) become increasingly important. And then at the level of the fourth dimension 4D, there occurs the fullest realisation of reflexive analysis.

The transformative agency of $4 \mathrm{D}$ aims for “...emancipation... in the free society where each individual's flourishing depends on everyone flourishing. 4D works to overcome the false sense of self as separate and isolated. We relate to the world and to other people through recognising what we share in common (Bhaskar, 2012: p. 305). The key questions concern identity (who am I?) and agency (what am I to do?)". (Alderson, 2016: p. 46). At this stage then, false consciousness (in the Marxian model) is shed, and alienation is unmasked. 
This combined model is called MELD-in summary:

1M: Basic values, which are often unseen or unrecognized, but which inform or control action (e.g. covert power systems and alienation).

2E: Seeds of hope, and the dawning of understanding and dialectics. The realisation of absence, of lack of fulfilment, and yearning for change.

3L: Understanding of how social structures constrain us.

4D: Critical reflection and social change.

Clearly, this is an ideal (and idealistic) model, and Bhaskar [13] warns us of the possibility of "malign MELD", in which negative, coercive powers subvert consciousness, control debates (e.g. through newspaper campaigns), and ensure that the powers of capital (in the Marxian model) are unassailed, however much information we have (e.g. on health inequalities, on educational underachievement, or on poor quality schools). The "seeds of hope" of $2 \mathrm{E}$ are often dashed.

Alderson devotes her two volumes (2013 \& 2016) to accounts of how, effectively, to liberate children so that their rights are fully realised. She uses the $1 \mathrm{E}$ assumptions about the "real" world and its state in nature: "Childhood and nature overlap in symbol and in practice... ways in which children are treated reflect activities towards nature. These range from neglect and abuse to violence that wastes potential and ends the lives of millions of children." (Alderson, 2016: p. 46).

Alderson then devotes her volumes to analysing children's lives (especially those in contact with health care systems) in detail, explaining how their condition is perceived and classified, and how they are treated-fit into the MELD hierarchy. "The DCR aim of promoting utopias is to negate alienation... schools are particularly good places for transformation, having the time, space and long-term relations to nurture utopian work... DCR concepts can assist teachers in being reflective, self-critical, and collegial... DCR's concrete utopian imagination is not a prescription for the future, but for an open society where individuals decide what to do with their freedom. It is an inner urge that flows universally from the lack of elemental absence (lack, need, want desire)." (Alderson, 2016: pp. 157-158).

Considering alienation's ending, Alderson speculates about the "natural communism" that would follow. In Alderson's formulation this communism goes beyond Marx (who merely wanted 'from each according to his ability, to each according to his need'): "Marx's... generous giving and taking is not possible if everything is already shared." (Alderson, 2016: p. 159) In this model, the needs, rights and interests of children are not separate, but shared, in the utopia which Alderson anticipates. Alderson's (2013) chapter on" Inner Being: Alienation and Flourishing" sums up, for us what is most inspirational in Alderson's critical realist theory of social science. She comprehensively demolishes the myth of "value free social science". Research with children, she argues, is not only value-informed: its entire goal in showing how children can "flourish" at the highest level of the MELD model is, as Bhaskar (1986) puts it, is "value saturated" at ${ }^{2}$ There is an intriguing parallel with Flaschel's (2009) idea that Marx's "reserve army of labour" will disappear if the social democratic state gives all citizens, whether working or not a generous living allowance, in his model of "flexisecurity". 
each step in the MELD framework:

Having reviewed support for value-informed social research, I now summarise MELD 4D, fourth dimension, where values are central... the traditional Hegelian dialectic is taken towards logical, consistent completeness... To include real being (ontology) and real transformation, MELD $1 M$ first moment begins with non-identity and absence, $2 E$ second edge involves negativity and oppressive power, $3 L$, third level, concerns open, dynamic totalities [of social structure] which move on to $4 D$, fourth dimension, of praxis, transformative agency in ethical practice and liberating power, the dialectic that is "the pulse of freedom". I hope that this chapter, by showing all the $M E L D$ moments, will help to clarify the meaning and relevance of some earlier parts of this book. They all relate to the DCR logic that human beings inevitably desire and move towards freedom and justice, and that this is or should be the central concern of social science ... When individuals are out of touch and alienated from their body and nature (plane 1), from other people (plane 2), and from structures and institutions (plane 3) they can become unable to act in order to absent the absences and power 2 [of oppressive forces], and they are denied the capacity for transformation at MELD $4 D$. (Alderson, 2013: p. 138).

Although DCR is a complex philosophy for social science research, Alderson's reconstruction of her previous research with children using the DCR framework, which she elucidates in the passage quoted above, is both enlightening and enervating. The reader's journey in following this difficult intellectual model seems justified. According to Bhaskar (2008): "Practical, concrete utopianism stands in contrast to abstract, intellectual utopianism... being practical involves absenting constraining absences, as each in their own way, human beings try to overcome power 2 and "master-slave" relations' in society and nature... the dialectic is an inner urge that flows universally from the logic of elemental absence (lack, need, want, desire)... against power relations towards freedom as flourishing." (Bhaskar, 2008). This theme Bhaskar elaborates in his monograph From Science to Emancipation: Alienation and Enlightenment (2012).

Priscilla Alderson's (2013) reflections on the religious origins of "theories of the self" in critical realist theory are fascinating too, for the student of self-concept: she writes that: "Ideas about the self, illuminate the fourth plane of social being, the inner self, and MELD 4D on flourishing, and its converse, misery." (p. 140).

Consideration of the soul, the inner or spiritual self, may be outside of the bounds of conventional sociology, but for Alderson "DCR explores unseen deeper realities, and shows the problems in social research that ignores them... Without some explicit theories of human nature and the young self... [research] ignores concepts of harm and benefit to children... ideas from religion and philosophy seep into common imaginings of the self... they [Jesus, Muhammad, Buddha] exemplified "childlike" humility, poverty, humility, vulnerability, willingness to admit ignorance and to learn, with obedience to a transcendent goodness and an innocent detachment from worldly power." (Alderson, 2013: pp. 141-142) Alderson then turns back to her mentor, Bhaskar (2000) who "theorised an embodied personality, a psychic being or soul or anima, and a 
ground state, all three striving for humanity."

Shipway (2013) writing about critical realism's contribution to the discipline of education comments on $\mathrm{CR}$ as a philosophical and a transcendental (spiritual) model that "encompasses educational administrators and policy makers, teacher educators, and philosophers of education in what they do and think." CR uncouples itself from postmodernism, enabling researchers to describe the "real" world through a grounded, value ontology. Shipway cites Collier (1994): “...critical realism is an ongoing research programme within the human sciences, and in particular in their theoretically and politically contentious border areas. It is certainly not a completed system which can be applied in these fields to solve all problems: on the contrary, by treating scientific projects as explorations of realities with inexhaustible depths, it helps to keep these projects open for self-criticism and development."(Collier, 1994: p. 236).

According to Shipway (2013) CR has “an emancipatory mission” for research and practice in education. "Critical realism supports a stratified, democratic use of homol$\mathrm{ogy}^{3}$, and the exercise of power is a vital condition for the possibility of emancipation of students and those who work with them.” (p. 5).

\section{Matthew Wilkinson: Dialectical Critical Realism and Islam}

The generosity of the shared dialectical process also flows from Wilkinson's (2013 \& 2015) analysis of Islam. He too uses the MELD hierarchy, and concludes his 1E analysis: "The Islamic Critical Realism (ICR) fulcrum offers the philosophical possibility that God may have granted genuine spiritual insight to those who fall outside one's own religious tradition and this can enrich rather than threaten one's own commitment to faith and facilitate a genuinely respectful engagement with the "other". (p. 64).

Moving to 2E, Wilkinson observes how Bhaskar (2008) adapted Hegel: "He radically alters the phases of dialectic into non-identity, to absence, to totality to transformative praxis in an extension of the "revindication" of ontology and the positing of a new ontology of original critical realism.” (p. 66) Further, on absence, Wilkinson observes: "According to critical realist thinkers, absence, negativity and change are essential parts of the duality of presence and absence in being (Norrie, 2010). For example silence is the precondition of speech, rests are indispensable to musical sound, and as we know from natural science, empty space is a necessary condition of solid objects. In the experience of selfhood, a senselknowledgelbelief that ' $I$ am this' necessarily entails a sense/knowledge/belief that 'I am not that." (Wilkinson, 2015: p. 66).

DCR's concept of absence is for Wilkinson, crucially transformative. "Indeed, dialectical change is understood by critical realists as the process... of remedying or removing absence" (Bhaskar, 2008). For Bhaskar, positive change is often the removal of, or progression from, something negative. The archetype of this movement is the process of abolishing (i.e. absenting) the conditions of slavery-and on the meaning of the "master-slave" relationship Bhaskar has much to say.

"Homology" is a term borrowed from biology which explains the link between "the transcendental realist world view”, and Roy Bhaskar's political model of socialism (Collier, 1998: p. 469). 
In Wilkinson's (2015) account of the journey towards combining British and Islamic citizenship in Muslim adolescents he first paints the 2E picture of absence, and the "absence"' of seriousness' in British National Curriculum goals concerning citizenship education. But as his research progressed, Wilkinson moved to $3 \mathrm{~L}$, the level of 'seriousness'. As an example, he cites Lovelock's (1979) idea of Gaia, the self-regulating, self-healing universe, which he relates to the Qur'anic idea of kalifa or stewardship of the earth. At this level, DCR concepts allowed Wilkinson to focus on transformative ideas, on the notion of the primacy of structure over individual agency. At the $4 \mathrm{D}$ level, the meaning (and pedagogy) of citizenship education was taken outside of the classroom into "the world", so that "...unity-in-diversity is the bedrock of society, in which institutional structure both predominates over individual agency and can be transformed by it. This task of linking agency with structure means that more than any other subject at the level of $4 D$ (Fourth Dimension-transformative praxis), citizenship education needs to be carried outside of the classroom into the community." (Wilkinson, 2015: p. 246).

\section{Margaret Scotford Archer and Reflexive Morphogenesis}

Archer is, in our reading, the most impressive of the sociologists who have been inspired by Bhaskar's critical realism, and its unfolding from and through Marxism and Hegel into dialectical critical realism, into realms of ideology and how in critical realist theory, we may understand and apprehend notions of transformative social action (Archer, 1995-2014).

Bhaskar's (2008) earlier consideration of (and modification of) Marxian theory had led some American commentators to label him as a Marxist (and hence the virtual boycott of DCR by American sociologists-Gorski, 2013. However, transcending the purely material concerns of Marxian ideology, Bhaskar embarked on a spiritual journey, exploring Hindu and Buddhist concepts of self (Bhaskar, 2000). Archer too considers "spiritual" themes in her numerous writings on DCR, and ways by which individuals through contemplation, self-analysis and dialogue can lead to social change.

Archer's fullest and most eloquent account of "the internal conversation" for us is her 2003 volume Structure, Agency and the Internal Conversation. Her arguments concern "structure" (which has variable meaning in philosophy and sociology, but is seen as an enduring form within society), and "agency" (with similar debates about its meaning, but intuitively, how individuals relate, subjectively, to social structure). Both structure and agency exist independently (i.e. have ontological reality), and causal relations between them, in any case study, remain to be investigated. Structure and agency "are two distinctive and irreducible properties and powers, and... human reflexive deliberations play a crucial role in mediating between them.” (Archer, 2003: p. 14). Thus reflexivity is central in Margaret Archer's sociology: "Were we humans not reflexive beings there could be no such thing as society. This is because any form of social interaction, from the dyad to the global system, requires that subjects know themselves to be themselves. Otherwise they could not acknowledge that their words were their own 
nor their intentions, undertakings and reactions belonged to them... not one social obligation, expectation or norm could be owned by a single 'member' of society." (Archer, 2003: p. 19).

Moreover, the reflexive, internal conversations and self-appraisals of individuals in their interactions with others have, in Archer's model, causal power in modifying structures: these "extrinsic effects... mediating cultural and social properties of their societies... and the private lives of social subjects are indispensable to the very existence and working of society." (Archer, 2003: p. 52).

Archer draws ideas and insights on the social psychology of the self, described in the writings of James (1890) and Mead (1964), whose ideas of self-other, and I-myself, Archer analyses in detail, but is critical of their ideas of "personal reflexivity": their idea of the "inner world" lacks autonomy in relation to the individual's "outer world" a crucial shortcoming, in Archer's goal to "reclaim the internal conversation" as talking "to" society, not merely "about" society. Only then, Archer (2003: p. 129) proposes “...we are in a position from which properly to consider the potentialities of our reflexive deliberations as the process which mediates between 'structure and agency". Archer illustrates her thesis by analysing the "internal conversations" of twenty adults, making each a unique case study, in showing inter alia, "How the different individual modes of reflexivity, which mediate constraints and enablements in quite distinctive ways, are also related to collective action." (Archer, 2003: p. 166).

Reflexivity does not usually lead to structural change, of course, and Archer illustrates why this is so in her analysis of types of reflexivity. But, reflections upon reflections are refined, shared and polished reflexives: “'Meta-reflexives'... are such because they pursue cultural ideals that cannot be accommodated by the current social structure and the array of contexts it defines... By personifying their ideals of truth and goodness, the meta-reflexives awaken them and re-present them to society. In so doing they re-stock the pool of societal values, by displaying alternatives to the aridity of third-way thinking-and its repressive consensus..." (Archer, 2003: p. 361).

A useful critique of Archer's "reflexivity and conduct of the self" has been offered by Akram \& Hogan (2015), who examine how Archer's idea of self-reflexion may challenge ideas of the "taken-for-granted" everyday events in the lives of individuals which form part of Bourdieu's (1986) account of habitus. Bourdieu downplays ideas of freely willed choice in making decisions, focussing instead on how social and economic classes create reserves of social capital, through socialising those below them into "unconscious acceptance" of everyday lifestyles. This habitus of the labouring classes, and of the reserve army of labour is said to be deeply entrenched. The sub-proletariat's only mode of upward mobility, like that of the proles in Orwell's 1984, is to win the lottery. Yet despite this gloomy continuity of class, Bourdieu allows that "misrecognition" (akin to Marx's "false consciousness") can change over quite lengthy periods of time, or change in response to sudden upheavals, such as war. Bourdieu has appeal for some radical sociologists in that he seems to have identified how socio-economic classes perpetuate themselves through symbolic rituals which can be enduring across generations: 
but these rituals may also be identified, and changed (e.g. Carlile, 2013; Stahl, 2015; Savage, 2015).

Archer's idea of morphogenesis, as part of a self-reflexive change in self-concept, a path to "social mobility" seems a light year away (or perhaps a "second edge" away in CR terms) from the rather depressing portraits of everyday social life which come from detailed ethnographic portraits of working class life which students of Bourdieu paint. For Akram \& Hogan (2015), Archer proposes “...a seismic shift [from Bourdieu's account] in how people form and conduct themselves in everyday life, a process that would result in the realization of extremely high levels of ethical autonomy... she goes beyond Giddens' and Bourdieu's notions of everyday, routinized taken-for-granted actions... offering an entirely new view of how people form, manage and understand themselves in everyday life." (p. 610) [italics in original].

Archer (like Alderson, 2013: p. 80) does not reject Bourdieu's account of "everyday habitus", but offers instead a novel form of social psychology of everyday life. What is novel (among other things) is Archer's idea of agency, which is developed within the framework of Bhaskar's dialectical critical realism. Personal reflexivity (renewing one's own thoughts, feelings and actions in relation to those of others) is shared, according to Archer, by all people who find themselves in a common social situation. Akram \& Hogan (2015) sum up their understanding of Archer's position: "Reflexivity is the regular ability, shared by all normal people, to consider themselves in relation to their social contexts and vice versa... Reflexivity in modern society means a transition from a morphostatic to a morphogenetic society of constant change. Reflexivity is also linked to our emotional commitments and our moral concerns... all of which help to maintain 'the internal conversation' which reflects ongoing conversations in agents about who they are, and how they see their lives progressing... Archer's work raises the idea that individuals think about who they are (in the sense of personal and social identity) and modify their identity in the course of everyday being... Central to such a practice of the self is a deep sense of awareness of who one is, how one became who they are, and the benefits of pursuing such new performative aspects of identity". (Akram \& Hogan, 2015: p. 620).

In this new world (for it seems too exciting to be like the old world which we all remember): "Reflexivity emerges from a new social and cultural order, which creates novel situational contexts, and which they must negotiate... In such a scenario, agents draw upon their socially dependent, but nevertheless personal powers of reflexivity to define their courses of action... Reflexivity is not necessarily positive, because it can also have negative outcomes... some will be taking the best course, but may make mistakes... not all reflexion is successful, but all are crucially trying to be reflexive." (Archer, 1995: $p$ 110).

In Making our Way through the World (1995) Archer argues that there is movement between modes of reflexivity, taking the agent through the various levels of the MELD model (or not, as the case may be). But at each level the individual's "internal conversation" is crucial. Archer (2012: p. 13) defines four types of reflexivity, which can occur at 
any of the MELD levels: "Communicative Reflexivity (conversations with others, before they can lead to action); Autonomous Reflexivity (internal conversations that are selfcontained, leading directly to action); Meta-Reflexivity (internal conversations about critical actions within society); Fractured Reflexivity (broken or negative conversations). And reflexivity can assume crucial importance in times of stress and change. Progress and change are not inevitable."

Akram \& Hogan (2015) are impressed by Archer's thesis, and comment: “Archer's work raises the idea that individuals think about the way they are (in the sense of personal social identity) modifying their identity in the course of everyday being... But what does it mean when she says that agents regularly rethink and evaluate their everyday being? ... Central to such a practice of self-reflexion is a deep sense of awareness of who one is, how one became who they are, and the benefits of pursuing such new performative aspects of identity." (Akram \& Hogan, 2015: p. 621).

Akram \& Hogan raise important questions of how different Archer's idea ofself-reflexion is from Bourdieu's notion of habitus: or at least, how one moves from one state of being, or knowledge, to another status. Archer's objections seem to be to Bourdieu's philosophical assumptions in his methodology (which Bhaskar would likely have rejected as flawed) in arriving at his model: she does not object to Bourdieu's moral impulse, which at the end of the day, seems close to her own.

This is a fruitful area for qualitative research, for eliciting extended accounts of how people in specific communities, or with shared pasts (e.g. ethnicities, childhood experiences) construe themselves through their intellectual, moral and emotional histories, their reactions to others, and how they share thoughts, feelings and opinions. The agents in such a study might be people undergoing change in their lives and who are making choices for the future, reflecting on their past: a population of senior high school students might be ideal for such a study. Would the results confirm Archer's idea of achieving social mobility through self-reflection, or Bourdieu's idea of achieving personal change through the absorption of new ideas? We suspect that both ideas might, dialectically, be confirmed, or a new synthesis of both views might emerge: perhaps the four stage MELD model might even be applied to the results.

Margaret Archer (2014) replaces the idea of postmodernism with that of "late modernity", enabling a "trajectory towards a morphogenetic society". That, in Marxist terms, would be a society liberated from the oppression forces of alienation ${ }^{4}$.

\section{Critical Realism's Marxist Dimension}

Throughout Critical Realist writing there is mention of Marx, much of it critical, although Bhaskar (2008) clearly draws inspiration from Marx and Hegel, even when he is moulding their ideas creatively into an entirely new way of understanding "society and nature." Collier (1994) writing about critical realism before Bhaskar developed his in-

${ }^{4}$ This latest phase of Margaret Archer's work (2014) brings together scholars writing from a critical realist model of emancipation which goes beyond that of traditional writings on class struggle, political power, and social progress. This work reflects her role as Founding Director of the Pontifical Academy of Social Sciences in Lausanne, and her appointment as Chief Advisor on Women's Issues, to Pope Francis. 
fluential ideas concerning dialectical critical realism, observed: "On the basis of the critical realist solutions to these questions [e.g. how to reconcile structural causality with effective human agency] I suggest that Marxian social science is about constraints on the reproduction and transformation of social structures. The knowledge of these constraints is the ground for political judgements: constraints on the reproduction of society show how it cannot reproduce itself without developing certain destructive features ..." (p. 234: italics in original).

This implies that critical realism should, like Marxism, be concerned with alienation, the separation of the individual from the "natural" status implied by their relationship to the social equity required by "labour" (employed, for example, in schools in the world of subordinated learning). This alienation, a form of habitus, is an "enslaving ideology" transmitted between generations: CR's (and DCR's task) is to "unmask" this alienation, and replace "false consciousness" with reflexive knowledge which enables social structures, and individuals interacting with structures, to reach a state of selfhood that melds them in the utopian awareness that may be the natural state of humankind.

There is lyrical parallel to morphogenetic insights, in the model of "wonder" which Ahmed (2004) derives from the writing of Descartes (on the body's first passions of cognitive surprise) and the "sensuous certainty" which Marx describes in the first dawning of consciousness in the unmasking of alienation: "The body opens as the world opens up before it; the body unfolds into the unfolding of a world that becomes approached as another body. This opening is not without its risks. wonder can be closed down if what we approach is unwelcome... But wonder is a passion that motivates the desire to keep looking, it keeps alive the possibility of freshness, and vitality of living that can live as if for the first time... wonder involves the radicalisation of our relation to the past, which is transformed into that which lives and breathes in the present." (Ahmed, 2004: p. 180).

Critical Realism, in Daniel Little's (2012) analysis sees critical thinking as "emancipatory". In both Marxist and CR traditions the term "critical" has specific meaning. Thus Bhaskar (2008) develops Marx's Feurbach thesis: "The philosophers have sought to understand the world: the point however is to change it." In this model, critical social science is an engaged or committed scientific endeavour, aiming to construct knowledge that may be, according to CR's emancipatory paradigm, for humanity's long-term benefit. Like Marx's Capital (2013) which was subtitled “a critique of political economy", CR also attempts to expose the underlying ideologies of powerful interest groups, and to expose "false consciousness".

On the difficulties of research findings actually leading to change, Alderson (2013) observes: "Many childhood researchers are disappointed that their 'participative research" ends with the neat reported findings (words) seldom leading to real, messy, transformative change (deeds). DCR helps to identify and remedy this problem, in following Marx by identifying five types of practical contradictions to be resolved if real change is to occur." (p. 91). Alderson continues her analysis of DCR in Marxist mode 
in discussing Bhaskar's (2008) borrowing from Marx on the idea of "the master-slave relationship", which goes beyond the power of "masters" in older societies to all kinds of power relationships: "Master-slave' relationships involve Marx's understanding of concepts that are central to DCR [identifying]... forms that have immanent contradictions that can suggest an ideal and misleading representation of the world; and also a real world that can be described, classified and explained in various, changing and developing ways. Marx, as a scientific realist, believed that explanatory structures are essentially not only distinct from, but are often... in opposition to the phenomena they generate. Examples include the way many schools fail many of their students..." (Alderson, 2013: p. 111).

Marxist scholars who have identified "master-slave" relationships in schools are, for example Bernard Coard (1971 \& 2005) on the labelling of Black children as "subnormal"; Willis (1979) on working class boys "learning to labour"; and Grant Banfield's (2016) perspective on Marxism and education. For Bhaskar (2008) [6], "The ruling classes claim their enduring power, far from being abuse of the slave by his master, is their right and duty (like the colonial "white man's burden") and is also in everyone's best interests. This Marxist idea of false-consciousness, or mystifying of the reality, is propagated as a routine part of class power" (Alderson, 2013: p. 116).

Grant Banfield (2016) in his Critical Realism for Marxist Sociology of Education uses the terms "Marxist" and "Marxian" interchangeably. This, we infer, is a way of saying that although he is a Marxist, he is certainly not a Marxist-Leninist. He defers to Roy Bhaskar's “spiritual socialism”, quoting Bhaskar's early (1986) writing: “I take it that whatever our politics... socialists can agree that what we must be about today is the building of a movement for socialism-in which socialism wins a cultural hegemony, so that it becomes the enlightened common-sense of our age." (p. 1).

Banfield tells us that his "starting premise" is that Marxian education is in Marx's words "revolutionary practice." According to Banfield: "Education is part of what Gramsci has actually called "the war of position" ... where the trenches of civil society are won in classrooms, workplaces, pubs and on street corners, that socialism becomes... the enlightened common-sense of our age. According to Bhaskar, not only is there an elective affinity between critical realism and historical realism, but also the original intent of critical realism was to support the science of history that Marx had opened up... it is in their differences that the real possibilities of a working relationship between critical realism and Marxism are established.” (Banfield, 2016: p. 1). This last point is important: DCR may draw on Marxist ideas, but it goes beyond Marx's interpretation, e.g. his use of Hegel. Furthermore, "A crucial defining feature of critical realism is the seriousness with which it takes ontology. This seriousness is an antidote to what we will see as tendencies in fields like the sociology of education (and Marxist sociology of education) to ontological shyness." (Banfield, 2016: p. 3).

An ontology based on the stratified, four-level MELD model, illustrates “... Bhaskar's stratified, differentiated... real ontology indicating that what appears and is immediately experienced are only surface features of deeper realities... Bhaskar's emergentist 
ontology allowed him to advance an emancipatory critique of human-harming social structures... with understanding of the structural causal relations underlying them comes an ethical responsibility to negate and overturn them. Science is simultaneously a social and emancipatory practice: the underlying methodological content common to both the natural and social sciences is emancipation: Bhaskar's dialectic of 'the pulse to freedom."' (Banfield, 2016: p. 4).

As Shipway (2013) observes in his A Critical Realist Perspective of Education, schools are particularly appropriate places for a (Marxian) critical realist analysis and reconstruction of values and social structure. They contain, and control (and often harm) our precious children; they are the state's agents of socialization; they control and discipline, preparing the young to be rulers, administrators, technicians, labourers, excluded minorities, or the reserve army of labour-according to their various rituals, and social structures ranging from those of the "public" schools to the "crumbling comprehensive" servicing run-down, estates of public housing (Bagley, 2008).

The conclusion is that critical realism enriches and humanises Marxism, and counters the development of reactionary themes such as "the dictatorship of the masses". DCR's spiritual aspirations concerning the soul and the self also enrich the insights of Marxism. Alderson's (2013 \& 2016) use of Bhaskar's four level-analysis in writing about children and their emancipation, their flourishment, and their possibilities for fulfilled and non-alienated lives is profoundly creative, and inspirational. Collier (2002) argues that critical realism "can add to Marxism without taking anything away" but he acknowledges that some of his fellow authors (in an edited volume on Critical Realism and Marxism), may disagree.

We conclude this section with the views of Creaven (2007) [5], who is the most enthusiastic of the "Marxist critical realists". Examining how Marx and Engels worked together, he observed that Engel's was the "underlabourer", clearing away the underbrush of false ideas and philosophical nonsense that impeded the clarity of Marxian ontological analysis. (Wilkinson, 2013 \& 2015 too uses the idea of underlabouring, which clarifies the road to emancipation in the critical realist model). Engels' survey of "the condition of the working class in England" (1845/1978) was one of the underlabouring tasks for Marx's (2013) theory of Capital, for instance. In Creaven's (2007) analysis: "Marxism was already, implicitly a critical realist social theory." Thus Bhaskar's evaluative realism, "...provides (in Marx's phrase) "an ethical basis for championing the struggles of the oppressed" as a natural principle of justice.” (p. 29).

In his recent writing, Creaven (2015) uses the Bhaskar's dialectical model to resolve the tensions between the "two Marxisms" structuralism, and humanism-attempting to show that there is a "coherent unity" between the two forms.

\section{Application of Critical Realism models in Different Fields of Research}

Critical realism and "social ontology" models have become increasingly popular with researchers in several areas of social science research, although the bulk of research is 
still undertaken with children and adolescents in educational, health and social care settings, and in research fields such as race and ethnic relations (e.g. Bhaskar \& Danermark, 2006; Sarra, 2011; Bagley \& King, 2003; Scambler, 2012; Carter, 2000). These various researchers reflect Bhaskar's critical realist model of social organisations which advocates strategies of emancipation through understanding the "real nature" of oppressive forces (Bhaskar, 2012), and Collier's (2002) radical interpretation of DCR. A fascinating feature of CR is the model's ability to attract (and integrate) Marxist, Muslim and seemingly conservative Christian scholars in addressing (and sometimes uniting their approaches) with regard to significant social problems, and areas of change (Archer, 2014).

One interesting development is the growth of CR research in the area of industrial sociology, and human relations management (Zacharialis, Scott, \& Barrett, 2010), including a textbook (Edwards, O’Mahoney, \& Vincent, 2014), which includes case examples of how to approach organisations using research models in the CR mode, to collect relevant data, and interpret it using dialectical critical realism.

Easton (2010) also offers a very useful guide to case study research using critical realism, for use in organisational, business and human relations management. In Easton's CR model, the case study must be grounded on a firm ontological basis of "truth", of a description of the nature and implicit values of the organisation studied. He recites the "basic assumptions" of CR: "Firstly, the world exists independently of our knowledge of it; secondly, our knowledge of the world is fallible, self-deceiving, cloaked in implicit or poorly-organised theories whose assumptions are not often explicit-thus our initial concepts of truth and falsity often fail to provide a coherent view of the relationship between knowledge and its object; thirdly, the realm we wish to research is differentiated and stratified... by actions, texts and institutions, and they are all concept dependent." (Easton, 2010: p. 120).

Easton urges: "Critical realism first of all makes the ontological assumption that there is a reality, but it is usually difficult to apprehend. I distinguish between the real world, the actual events that are created by the real world and the empirical events which we can actually capture and record. Thus we will always be surprised about the nature of the real... The research process is one of continuous cycles of research and reflection. The final result is the identification of one or more mechanisms that can be regarded as having caused events." (Easton, 2010: p. 128).

Two Muslim researchers (Abubaker \& Bagley, 2016a, 2016b) have used the critical realist approach with apparent success, in studying Work Life Balance (WLB) benefits available to female employees in telecommunication companies in Jordan and Palestine. The grounded ontology of these studies is that the realist framework which constrains employers in Islamic countries is that of the values and rituals of Islam (including deference to authority, and the care of employees), rather than those of profitmaking. These traditional values require for example, accommodation of the needs of women, who in consequence enjoy a better quality of work-life balance benefits than do female graduates in Western countries. We make the point also that Islamic rules con- 
cerning enterprise, profit and interest mean that the capitalist mode of profit-making and exploitation of workers, and their resulting alienation which Marx (2013) had described do not normally pertain in business enterprises in many nations, an important factor for multinational investors extending manufacturing and marketing in Arabic countries. This model of "welfare capitalism" deserves further research.

\section{Conclusions and Reflections on Dialectical Critical Realism}

In reading Bhaskar, Alderson, Wilkinson and Archer and other critical realists' article, we have been struck by a new facet of communication and information which influences all of our lives: the electronic information system of the web from which we are constantly gleaning information; as well we are sending frequent e-mails and texts, share ideas and images with friends (and others) on various sites. The youngsters among us are no longer truly part of themselves: we share ourselves, reflexively, with a much wider world than when Roy Bhaskar published his first major book, in 1986. What is the meaning of this electronic world? Alderson (2013: p. 102) is worried about the covert collection of children's electronic data as a means of controlling them, an electronic version of Bhaskar's (2008) "master-slave" relationship. But there is also a powerful anarchy in the data which is collected on all of us, and liberation when it is released through the integrity of "whistle-blowing".

And finally, what is of the older adolescents whose "souls have been murdered" (as Schatzman, 1973 puts it). We are referring here to our work on adolescent women who lead shadow lives because of the chronic physical and sexual abuse they have endured (Bagley \& King, 2003; Bagley \& Sawyerr, 2017). The qualitative researcher will elicit these accounts from her informants. But then, how should she intervene (as intervene she must)? And, returning to Alderson's (2013 \& 2016) reconstruction of her earlier work with children, how might the researcher help these adolescent women achieve a self-actualization of identity?

Alderson observes that: "Children and adults learn about their needs through their bodily experiences within relationships; they express their needs and views through their bodies; and they are respected or disrespected in the casual or harsh ways in which their bodies are treated in practice" (Alderson, 2013: p. 94). She is writing about her research with physically challenged children, but these words could have been written about physically and sexually abused children. How can Archer's (2007) inspiring message of personal growth help us in bringing these children and adolescents through "absence" to their fullest potential? Alderson's (2016) critical realist model for realising the rights of children in a variety of international contexts gives us a significant lead.

Finally, we want to emphasize how exciting and life-changing critical realist theory may be. Once the scholar has absorbed this writing (or their personal version of it, since different actors will perceive DCR writings differently, and take away different aspects of the model in their quest for truth-telling and social change) their intellectual and emotional lives will never again be the same. Reflecting, thinking, feeling, relating to one's own thoughts and those of others in the realist, morphogenetic mode is exciting, a 
daily excitement which is never lost.

We are empowered by Bhaskarian concepts in being confident that our value judgements and the actions that derive from them can be important: in research we now move easily from "is" to "ought", and reflexively through dialogue and debate with academic and professional partners, setting new goals and horizons for achieving liberation, and seeing ways of escape from alienation and "false consciousness" imposed on ourselves and others.

Critical realism gives to the scholar what Ahmed (2004) calls a sense of "wonder" in rediscovering and redesigning the social matrix of his or her world: "This critical wonder is about recognising that nothing in the world can be taken for granted, which includes the very political movements to which we are attached. It is this critical wonder about the forms of political struggle that makes Black feminism such an important intervention, by showing that categories of knowledge (such as patriarchy or "women") have political effects, which can exclude others from the collective..." (Ahmed, 2004: p. 182).

\section{References}

Abubaker, M., \& Bagley, C. (2016a). Work-Life Balance Policies in Jordanian Telecommunication Companies. Eurasian Journal of Business and Management, 4, 13-18. https://doi.org/10.15604/ejbm.2016.04.03.002

Abubaker, M., \& Bagley, C. (2016b). Work-Life Balance and the Needs of Female Employees in the Telecommunications Industry in a Developing Country: A Critical Realist Approach to Issues in Industrial and Organisational Social Psychology. Comprehensive Psychology, 5, 1-12. https://doi.org/10.1177/2165222816648075

Ahmed, S. (2004). The Cultural Politics of Emotion. Edinburgh: Edinburgh University Press.

Akram, S., \& Hogan, A. (2015). On Reflexivity and Conduct of the Self in Everyday Life: Reflections on Bourdieu and Archer. British Journal of Sociology, 66, 606-625.

https://doi.org/10.1111/1468-4446.12150

Alderson, P. (2013). Childhoods Real and Imagined: An Introduction to Critical Realism and Childhood Studies. Abingdon, UK: Routledge.

Alderson, P. (2016). The Politics of Childhoods Real and Imagined: Practical Application of Critical Realism and Childhood Studies. Abingdon, UK: Routledge.

Archer, M. A. (1995). Realist Social Theory: The Morphogenetic Approach. Cambridge: Cambridge University Press. https://doi.org/10.1017/CBO9780511557675

Archer, M. A. (2000). Being Human: The Problematic Agency. Cambridge: Cambridge University Press. https://doi.org/10.1017/CBO9780511488733

Archer, M. A. (2003). Structure, Agency and the Internal Conversation. Cambridge: Cambridge University Press. https://doi.org/10.1017/CBO9781139087315

Archer, M. A. (2007). Making Our Way through the World: Human Reflexivity and Social Mobility. Abingdon, UK: Routledge. https://doi.org/10.1017/CBO9780511618932

Archer, M. A. (2010). Conversations about Reflexivity. Abingdon, UK: Routledge.

Archer, M. A. (2012). The Reflexive Imperative in Late Modernity. Cambridge: Cambridge University Press. https://doi.org/10.1017/CBO9781139108058

Archer, M. A. (Ed.) (2014). Late Modernity: Trajectories towards Morphogenetic Society. New York: Springer. https://doi.org/10.1007/978-3-319-03266-5 
Bagley, C. (2008). The Educational and Social Inclusion of Disadvantaged Children in Britain. In C. Bagley, \& G. Verma (Eds.), Challenges for Inclusion (pp. 103-148). Rotterdam: Sense Publications.

Bagley, C., \& King, K. (2003). Child Sexual Abuse: The Search for Healing. New York: Routledge.

Bagley, C., \& Sawyerr, A. (2017). Child Sexual Abuse and Adolescent and Adult Adjustment: A Review of British and World Evidence, with Implications for Social Work, Mental Health and School Counselling. Advances in Applied Sociology.

Banfield, G. (2016). Critical Realism for Marxist Sociology of Education. Abingdon, UK: Routledge.

Bhaskar, R. A. (1986). Scientific Realism and Human Emancipation. London: Verso.

Bhaskar, R. A. (2000). From East to West: Odyssey of a Soul. Abingdon, UK: Routledge.

Bhaskar, R. A. (2008). Dialectic: The Pulse of Freedom (1st \& 2nd ed.). Abingdon, UK: Routledge.

Bhaskar, R. A. (2012). From Science to Emancipation: Alienation and Enlightenment. Abingdon, UK: Routledge.

Bhaskar, R. A., \& Danermark, B. (2006). Metatheory, Interdisciplinary and Disability Research: A Critical Realist Approach. Scandinavian Journal of Disability Research, 8, 278-297. https://doi.org/10.1080/15017410600914329

Bourdieu, P. (1989). Social Space and Symbolic Power. Sociological Theory, 7, 14-25. https://doi.org/10.2307/202060

Carlile, A. (2013). Permanent Exclusion from School and Institutions Prejudice. Rotterdam: Sense Publications. https://doi.org/10.1007/978-94-6209-182-5

Carter, C. (2000). Realism and Racism: Concepts of Race in Sociological Research. London: Routledge.

Coard, B. (1971/2005). How the West Indian Child Is Made Educationally Subnormal in the British School System: The Scandal of the Black Child in Schools in Britain. In B. Richardson (Ed.), Tell It Like It Is: How Our Schools Fail Black Children (pp. 27-59). Stoke: Trentham Books. (First Published in 1971 by New Beacon Books)

Collier, A. (1994). Critical Realism: An Introduction to Roy Bhaskar's Philosophy. London: Verso.

Collier, A. (1998). Explanation and Emancipation. In M. Archer, R. Bhaskar, A. Collier, T. Lawson, \& A. Norrie (Eds.), Critical Reality: Essential Readings (pp. 444-463). Abingdon, UK: Routledge.

Collier, A. (1999). Being and Worth. Abingdon, UK: Routledge.

Collier, A. (2002). Dialectic in Marxism and Critical Realism. In A. Brown, S. Fleetwood, \& J. M. Roberts (Eds.), Critical Realism and Marxism (pp. 168-186). Abingdon, UK: Routledge.

Creaven, S. (2007). Emergentist Marxism: Dialectical Philosophy and Social Theory. Abingdon, UK: Routledge.

Creaven, S. (2015). The "Two Marxisms" Revisited: Humanism, Structuralism and Realism in Marxist Social Theory. Journal of Critical Realism, 14, 7-53. https://doi.org/10.1179/1572513814Y.0000000008

Easton, G. (2010). Critical Realism in Case Study Research. Industrial Marketing and Management, 39, 118-128. https://doi.org/10.1016/j.indmarman.2008.06.004

Edwards, P., O’Mahoney, J., \& Vincent, S. (Eds.) (2014). Studying Organization Using Critical Realism. London: Oxford University Press. 
https://doi.org/10.1093/acprof:oso/9780199665525.001.0001

Engels, F. (1845/1978). The Condition of the Working Class in England. London: Penguin Books.

Flaschel, P. (2009). The Macrodynamics of Capitalism: Elements for a Synthesis of Marx, Keynes and Schumpeter. Berlin: Springer-Verlag.

Gorski, P. (2013). What Is Critical Realism? And Why Should You Care? Contemporary Sociology, 42, 658-670. https://doi.org/10.1177/0094306113499533

James, W. (1890). Selections from the Principles of Psychology. In H. Thayer (Ed.), Pragmatism: The Classic Writings (pp. 135-179). New York: New American Library.

Little, D. (2012). Varieties of Social Explanation: An Introduction to the Philosophy of Social Science. Boulder, CO: Westview Press.

Lovelock, J. (1979). Gaia: A New Look at Life on Earth. London: Oxford University Press.

Marx, K. (2013). Capital Volumes I and II. London: Wordsworth Classics.

Mead, G. (1964). Mind, Self and Society. In A. Strauss (Ed.), George Herbert Mead: On Social Psychology (pp. 115-284). Chicago: University of Chicago Press.

Norrie, A. (2010). Dialectic and Difference: Dialectical Critical Realism and the Grounds of Justice. Abingdon, UK: Routledge.

Popper, K. (2002). The Logic of Scientific Discovery. London: Routledge Classics

Sarra, C. (2011). Strong and Smart-Towards a Pedagogy of Emancipation: Education for the First People. London: Routledge.

Savage, M. (2015). Social Class in the Twenty First Century. London: Pelican.

Scambler, G. (2012). Resistance in Unjust Times: Archer, Structured Agency and the Sociology of Health Inequalities. Sociology, 33, 275-296. https://doi.org/10.1177/S0038038599000176

Schatzman, M. (1973). Soul Murder: Persecution in the Family. London: Allen Lane.

Shipway, B. (2013). A Critical Realist Perspective of Education. Abingdon, UK: Routledge.

Stahl, G. (2015). Identity, Neoliberalism and Aspiration: Educating White Working Class Boys. Abingdon, UK: Routledge.

Wilkinson, M. (2013). Introducing Islamic Critical Realism: A Philosophy Underlabouring Contemporary Islam. Journal of Critical Realism, 12, 419-442.

https://doi.org/10.1179/1476743013Z.00000000014

Wilkinson, M. (2015). A Fresh Look at Islam in a Multi-Faith World: A Philosophy for Success Through Education. Abingdon, UK: Routledge.

Willis, P. (1979). Learning to Labour: How Working Class Lads Get Working Class Jobs. Aldershot: Ashgate.

Zacharialis, M., Scott, S., \& Barrett, M. (2010). Exploring Critical Realism as the Theoretical Foundation of Mixed-Method Research: Evidence from the Economics of Information Science Innovations. Cambridge: Cambridge University Judge Business School. 
Submit or recommend next manuscript to SCIRP and we will provide best service for you:

Accepting pre-submission inquiries through Email, Facebook, LinkedIn, Twitter, etc. A wide selection of journals (inclusive of 9 subjects, more than 200 journals)

Providing 24-hour high-quality service

User-friendly online submission system

Fair and swift peer-review system

Efficient typesetting and proofreading procedure

Display of the result of downloads and visits, as well as the number of cited articles

Maximum dissemination of your research work

Submit your manuscript at: http://papersubmission.scirp.org/

Or contact aasoci@scirp.org 